\title{
Corruption and Economic Growth in Nigeria (1980-2013)
}

\author{
Ibrahim $\mathrm{W}^{*}$ and Okunade, Sheu $\mathrm{A}^{\dagger}$
}

\section{Abstract}

Corruption is as aged as the existence of man and it exists in all sphere of human life. The persistency of corruption erodes the social economic value of a nation. The study investigates the relationship between corruption and economic growth in Nigeria, in the period 1980-2013, using the VAR analysis. The study finds the existence of long-term relationship between corruption and unemployment growth on the economic growth of Nigeria. Also, the study found no short-term relationship in corruption and unemployment on economic growth. Hence, the result in the analysis shows that corruption positively has a strong influence on the output of Nigeria. So the rise in growth rate experienced in Nigeria is influenced by high corruption rate in the country, which is making the few rich to be richer, eradicating the middle class and making the poor to be poorer. Therefore, there is a need to develop political will to prosecute anyone found guilty of corruption irrespective of their position, tribe, religion or party affiliation. Such a punishment would also serve as a deterrent to others and help improve real economic growth and development.

Keywords: Gross domestic product, Government consumption, Inflation, Unemployment growth and corruption

Department of Economics, Al-hikmah University, Ilorin; ibraheed@alhikmah.edu.ng; olafuhad@yahoo.com

† Economics Department, University of Ibadan; okunade_sheu@yahoo.com 


\section{Introduction}

Corruption is a universal problem faced by both the developing and the developed countries. Although, according to Volejníková (2009) corruption was not given an explicit recognition in the traditional economic theories, it has in recent times become a globally recognized policy variable especially in less developed countries. According to Transparency International Organization (TIO), corruption is the misuse of public power for personal interests. This phenomenon is the result of weaknesses in the economic, political, and institutional performance of government. Shaxson (2007) argues that transparency international's definition of corruption is too narrow. While Knack (2007) states, that one cannot assign one definition to the work of Transparency International. The major obstacles to the comparative studies of corruption have been the lack of a general definition of corruption and the absence of objective cross-national data on corrupt behavior. Although corruption is more common in poorer economies, it does exist in all countries. Both economic growth and corruption are words that have been frequently used in public debates over the last few years. Economic growth is influenced by corruption either directly or indirectly through particular transmission channels. The aim of this paper is to study the impact of corruption on economic growth in Nigeria for the period 19802013.

The main rationale for embarking on this study came from a study by Selcuk Akcay (1999), which based his theoretical framework on the work of Mauro (1997). However, the present study differs in two aspects. Firstly, Selcuk Akcay (1999)examines the impact of corruption on economic growth across countries, for the period 1960-1995. However, the present study examines the impact of corruption on economic growth in Nigeria, covering the period1980-2013. Secondly, new control variable such as inflation rate (proxy for macroeconomic instability), is added to the model of the present study.

The second section of the paper describes corruption, its trends and classification globally and in Nigeria specifically. The third section reviews the literatures; the fourth section discusses issues in 
formulating methodology, model specification and empirical methods. The fifth section shows the analysis of results obtained and the last section concludes, by recommending appropriate policy for implementation.

\section{Study background}

Corruption, as defined for the purpose of this study, is "the abuse of public office for private (economic) gain". To a certain extent the corrupt practices that occur among private sector agents are excluded, although in practice both political and private corruption frequently overlaps. Corruption covers a considerable number of human actions, which in turn affect the operation of the Nigerian economy. Therefore, to analyze how corruption affects the economic growth in Nigeria, there is the need to unbundle corruption into specific human action. Corruption can be categorized in various dimensions to facilitate the understanding of how corruption affects economic growth. The concept includes three broad categories of human action: bribery, theft of public assets, and patronage. Corruption could be categorized based on how common and widespread it is and whether it is incidental or systemic. If corruption is perceived by the public as a regular behavior of public officials, then it is called "systemic".

Corruption is now recognized as a global phenomenon, which has to be addressed coherently and consistently. The need for concerted action in Africa is evident, and especially in Nigeria where corruption is said to be systemic. Corruption is deep rooted in Nigeria and its manifestation is reflected in the nation's scores in Corruption Perception Index (CIP) published annually by the highly rated Transparency International (TI). Nigerians were once universally respected and even honored. But, the question now is, what has changed? In order to take over the country from the Niger Company (Unilever) the British government paid 865,000 pounds, a huge amount in 1900. So frankly speaking, the British did not come to Nigeria to spread democracy because Nigeria started as a business to them. In the first republic (1963-1966), a politician who was the preindependence minister of labor and post-independence minister of finance was alleged to have increased tariff on imported shoes to 
protect its shoe industry in Nigeria. This same person was financing the NCNC political party, and no one bothered to ask where he got the money from, but according to Arrow Smith the money came from multinational companies. He was also responsible for bringing Julius Berger to Nigeria, which constructed the Eko-bridge in Lagos. Unfortunately, his willingness and dealings represented the beginning of corrupt practices in Nigeria public office holders. The first military coup in Nigeria took place in 1966 and the reason given by the military men was that: "our enemies are the political profiteers, the swindlers, the men in high and low places, that seek bribes and demand $10 \%$; those that seek to keep the country divided permanently so that they can remain in office as ministers or VIPs." Sadly, the same reason was given in every other coup that occurred after.

Despite the fact that Nigeria is blessed with an abundance of resources, particularly oil, and thereby considered a rich nation, it is not evident in the economy due to the presence of corruption in the country. African countries, including Nigeria, have to become more integrated into the global economy and attract greater levels of foreign and domestic investment if they are to achieve the growth rate necessary to reduce poverty and improve the wellbeing of their populations. Though, these will only make it possible to limit and not altogether eradicate corruption and to reduce the corrosive effects it has on African nations and societies.

\section{Literature review}

In literature on corruption, there are two major thoughts. On one hand, it has been argued by researcher such as Douie 1917,Leff (1964), Morgan (1964), Bayley (1966),Nye (1967),Huntington (1968), Friedrich (1972),Summers (1977),Lui (1985) and Acemoglu and Verdier (1998), that corruption aids economic growth vis-à-vis efficiency, particularly in the case of cumbersome regulation, excessive bureaucracy, market restriction or inefficient policies. According to Pak Hung Mo (2000), Corruption works like piecerate pay for bureaucrats, which induces a more efficient provision of government services, and it provides a leeway for entrepreneurs to bypass inefficient regulations. From this perspective, corruption acts as a lubricant that smoothens operations hence, raises the 
efficiency of an economy. On the other hand, researchers like: McMullan (1961), Myrdal (1968),Krueger (1974), Alam (1989),Vishny (1993),Mauro (1995), Tanzi (1997), andAliyu and Elijah (2008), argue that it reduces efficiency of the Economy. Corruption tends to hurt innovative activities because innovators need government-supplied goods, such as permits and import quotas, more than established producers do. Demand for these goods is high and inelastic; hence, they become primary targets of corruption Pak Hung Mo (2000). However, the actual effect of corruption on economic growth and its transmission process can be settled only empirically.

In recent years, there has been considerable empirical study on the impact of corruption. The emergence of indices on corruption enables researchers to do empirical studies about causes and consequences of corruption. These empirical studies reveal that corruption reduces growth and investment, increases poverty and inequality and distorts allocation of resources. The first econometric study on the impact of corruption on economic growth and investment across countries was done by Mauro. Mauro (1995, 1997) uses data from a sample of developed and developing countries to investigate the effects of corruption on economic growth, employing both Ordinary Least Squares (OLS) and Instrumental Variables (IV) estimating techniques. He finds that corruption has a negative and significant impact on economic growth. Most of the growth impact, he finds, comes through decreased investment in physical capita. Tanzi and Davoodi (1997) investigate the effects of corruption on economic growth and government expenditures. They find that corruption increases government expenditures but decreases expenditures on maintenance and thus leads to reduced economic growth. They also find that corruption decreases private investment. Gupta et al. (1998) find that corruption increases income inequality in a sample of developing countries. Hendriks et al. (1998) and Johnston (1998) find that the distributional effects of corruption and tax evasion are regressive, hence increases income inequality. Alesina and Weder (1999) investigate whether corrupt governments receive less foreign aid and conclude that corrupt governments receive more foreign aid under some circumstances. 
Li et al. (2000) investigate the effects of corruption on income and the gini coefficient of income distribution using data from Asian, OECD, and Latin American countries. They find that corruption increases the gini coefficient in a quadratic way. Aliyu and Elijah (2008) investigated the impact of corruption on economic growth from 1986-2007. Engle-Granger co integration and error correction mechanism (ECM) techniques were employed. The results show that corruption has significant negative effect on economic growth. The study discovers that corruption exerts both direct and indirect negative effects on economic growth in Nigeria. Nageri et al (2013), the study investigated the impact of corruption on economic development in Nigeria. The data were analyzed using the Ordinary Least Square (OLS) regression technique. The findings show that corruption has a significant negative effect on economic growth and development. Rotimi Ekundayo Mathew et al (2013), it studied corruption and the Nigerian economic growth. This study used the ordinary least squares (OLS) to determine the relationship between corruption and economy growth. The results revealed that corruption impairs and impacts economic growth. It is on this basis, we draw our conclusion and suggest that Private AntiCorruption Initiatives, Public anti-corruption initiatives and Public education campaign/programs should be strengthened and motivated to address the cause of corruption rather than its effects. Egunjobi (2013), this study empirically investigates the impact of corruption on economic growth in Nigeria on an annual time series data from 1980-2009 using regression analysis. Also, the Granger causality test and impulse response function was carried out. The empirical results reveal that corruption per worker exerts a negative influence on output per worker directly and also indirectly on foreign private investment, expenditure on education and capital expenditure per worker. The above empirical studies indicate best, mixed and conflicting results. This can be attributed in part to problems of methodology in these studies. For instance, while some of those studies used time series data, others used cross-national data thereby making it difficult to control for a number of cultural, historical, institutional, and qualitative differences in administrative rules and practices among others.

This study seeks to contribute to literature, using time series Nigeria data because most of the study either uses cross sectional 
or panel data to investigate the relationship between corruption and economic growth due to lack of corruption data. Obviously, the relationship between corruption and Economic growth remains ambiguous. As a result, the analysis of the impact of corruption on economic growth is very important for policy makers, in order to design appropriate anti-corruption policy.

\section{Methodology and Model specification}

In order to measure the impact of corruption on economic growth in Nigeria, the theoretical frame-work Selcuk Akcay (1999) is adopted for the analysis of this study, which based his theoretical framework on the work of Mauro (1997).Mauro (1995) extended Barro's framework by adding corruption to the growth equation. Mauro framework can be specified as follows:

$\mathrm{G}_{\mathrm{y}}(\mathrm{i}, \mathrm{t})=-\mathrm{a} \mathrm{y}(\mathrm{i}, 0)+\beta$ corruption + control variables $+\varepsilon$

Where; $G_{y}(i, t)=$ is the growth rate of per capita GDP of a country $i$ from period 0to period t.y $(i, 0)=$ is the log of a country's per capita GDP at time 0 in other words, Coefficient of $y(i, 0)$ is expected to be negative $(-\alpha)$ due to the theory of convergence. In estimating the relationship between corruption and growth, it is important to control other determinants of growth rate, to ensure that estimated coefficient capture the effect of corruption on growth.

Taking inference from the empirical findings and theories, which has been derived from the theoretical exposition of theory of convergence and then making corruption central to the equation, a model will be drawn up to determine impact of corruption on economic growth in Nigeria. If corruption and other control variables are taken as an independent variable then the model can be stated as:

$\mathrm{RGDP}=\mathrm{a}_{0}+\mathrm{a}_{1} \mathrm{CORR}_{\mathrm{t}}+\mathrm{a}_{2} \mathrm{CONS}_{\mathrm{t}}+\mathrm{a}_{3} \mathrm{INF}_{\mathrm{t}}+{ }_{4} \mathrm{UNEM}_{\mathrm{t}}+\mathrm{U}_{\mathrm{t}}$

Where: $\mathrm{RGDP}=$ Real gross domestic product, $\mathrm{CORR}_{\mathrm{t}}=$ corruption perception index, $\mathrm{CONS}_{\mathrm{t}}=$ government consumption/expenditure, $\mathrm{INF}_{\mathrm{t}}=$ inflation, $\mathrm{UNEM}=$ unemployment growth. $\mathrm{a}_{1}$ to $\mathrm{a}_{4}$ represents the slope coefficients, $a_{0}$ is the intercept and $U_{t}$ is the stochastic term or the error term at time t. The study adopts VAR for the estimation of causal relationship between the variables. The data of 
all the variables are sourced from the World development Indicator (WDI 2014). A-Priori expectation: $\alpha_{1}>0, \alpha_{2}<0, a_{3}<0$, and $\alpha_{4}<0$.

\section{Causality Test}

$\Delta R G D P_{t}=\alpha_{i j}+\sum_{k=1}^{m} \alpha_{11 k} \Delta R G D P_{t-k}+\sum_{k=1}^{m} \alpha_{12 k} \Delta C O R R_{t-k}+$ $\sum_{k=1}^{m} \alpha_{13 k} \Delta C O N S_{t-k}+\quad \sum_{k=1}^{m} \alpha_{14 k} \Delta \mathrm{INF}_{t-k}+$ $\sum_{k=1}^{m} \alpha_{15 k} \Delta \mathrm{UNEM}_{t-k}+\lambda_{1 k}$ ECTRGDP $_{t-k}+u_{1 t} \ldots 1.3$

$\triangle C O R R_{t}=$

$\alpha_{2 j}+\sum_{k=1}^{m} \alpha_{21 k} \Delta \operatorname{CORR}_{t-k}+\sum_{k=1}^{m} \alpha_{22 k} \Delta L R G D P_{t-k}+$ $\sum_{k=1}^{m} \alpha_{23 k} \Delta C O N S_{t-k}+\quad \sum_{k=1}^{m} \alpha_{24 k} \Delta I N F_{t-k}+$ $\sum_{k=1}^{m} \alpha_{25 k} \Delta U N E M_{t-k}+\lambda_{2 k}$ ECTCORR $_{t-k}+u_{2 t} \ldots \ldots .1 .4$ $\Delta$ CONS $_{t}=\alpha_{3 j}+\sum_{k=1}^{m} \alpha_{31 k} \Delta$ CONS $_{t-k}+\sum_{k=1}^{m} \alpha_{33 k} \Delta I N F_{t-k}+$ $\sum_{k=1}^{m} \alpha_{32 k} \Delta U N E M_{t-k}+\quad \sum_{k=1}^{m} \alpha_{34 k} \Delta R G D P_{t-k}+$ $\sum_{k=1}^{m} \alpha_{35 k} \Delta$ CORR $_{t-k}+\lambda_{3 k}$ ECTCONS $_{t-k}+u_{3 t} \ldots .1 .5$ $\Delta I N F_{t}=\alpha_{4 j}+\sum_{k=1}^{m} \alpha_{41 k} \Delta I N F_{t-k}+\sum_{k=1}^{m} \alpha_{43 k} \Delta R G D P_{t-k}+$ $\sum_{k=1}^{m} \alpha_{42 k} \Delta \operatorname{CORR}_{t-k}+\quad \sum_{k=1}^{m} \alpha_{44 k} \Delta \operatorname{CONS}_{t-k}+$ $\sum_{k=1}^{m} \alpha_{45 k} \Delta U N E M_{t-k}+\lambda_{4 k} E C T I N F_{t-k}+u_{4 t} \ldots . .1 .6$ $\triangle U N E M_{t}=$ $\alpha_{5 j}+\sum_{k=1}^{m} \alpha_{51 k} \Delta U N E M_{t-k}+\sum_{k=1}^{m} \alpha_{52 k} \Delta R G D P_{t-k}+$ $\sum_{k=1}^{m} \alpha_{53 k} \Delta$ CORR $_{t-k}+\quad \sum_{k=1}^{m} \alpha_{54 k} \Delta \operatorname{CONS}_{t-k}+$ $\sum_{k=1}^{m} \alpha_{55 k} \Delta I N F_{t-k}+\lambda_{5 k} E_{C T U N E M_{t-k}}+u_{5 t} \ldots .1 .7$

Analysis of result

Table 1.1: Co integration Result

\begin{tabular}{|c|c|c|c|c|}
\hline $\begin{array}{c}\text { Hypothesized } \\
\text { No. of CE(s) }\end{array}$ & $\begin{array}{c}\text { Eigen } \\
\text { Value }\end{array}$ & $\begin{array}{c}\text { Trace } \\
\text { Statistic }\end{array}$ & $\begin{array}{c}0.05 \text { Crit. } \\
\text { Value }\end{array}$ & Probability \\
\hline None* $^{*}$ & 0.858 & 111.955 & 69.819 & 0.000 \\
\hline At most $1^{*}$ & 0.593 & 52.413 & 47.856 & 0.014 \\
\hline At most 2 & 0.370 & 26.451 & 29.797 & 0.116 \\
\hline At most 3 & 0.339 & 12.576 & 15.495 & 0.131 \\
\hline At most 4 & 0.004 & 0.115 & 3.842 & 0.735 \\
\hline $\begin{array}{c}\text { Hypothesized } \\
\text { No. of CE(s) }\end{array}$ & $\begin{array}{c}\text { Eigen } \\
\text { Value }\end{array}$ & $\begin{array}{c}\text { Max-Eigen } \\
\text { Statistic }\end{array}$ & $\begin{array}{c}0.05 \text { Crit. } \\
\text { Value }\end{array}$ & Probability \\
\hline None* & 0.858 & 58.542 & 33.877 & 0.000 \\
\hline At most 1 & 0.593 & 26.962 & 27.584 & 0.059 \\
\hline At most 2 & 0.370 & 13.875 & 21.132 & 0.375 \\
\hline At most 3 & 0.339 & 12.462 & 14.265 & 0.095 \\
\hline At most 4 & 0.004 & 0.115 & 3.842 & 0.735 \\
\hline
\end{tabular}


Table 1.1 above shows co integration test result. Both the trace test and the maximum-Eigen value test indicate two co integrating equations at $5 \%$ critical value. These indicate that null hypothesis of no co integration can be rejected at $5 \%$ critical value for both the trace test and maximum-Eigen value test. Therefore, Johansen co integration test shows evidence of long-run relationship between the variables considered. Usually, for variables that are co integrated, error correction model based causality test is employed to identify the direction of both short-run and long-run causality.

Table 1.2: Long-run causality

\begin{tabular}{|c|c|c|}
\hline Long-run Causality & CointEq1 & CointEq2 \\
\hline Real GDP (-1) & 1.000 & 0.000 \\
\hline Inflation(-1) & 0.000 & 1.000 \\
\hline Consumption (-1) & $-0.033[-0.331]$ & $-7.049[-7.089]$ \\
\hline Corruption (-1) & $0.355[-3.669]$ & $5.787[1.853]$ \\
\hline Unemployment $(-1)$ & $-1.077[-3.669]$ & 25.354 [8.714] \\
\hline
\end{tabular}

Source: Computed by the researcher using E-view 7.0

Table 1.2 above shows that t-statistics value of corruption and unemployment growth are statistically significant in the real GDP equation and inflation equation. These indicate the existence of long-run causality, from the corruption and unemployment growth to real GDP and inflation respectively. Corruption has positive long-run relationship with both GDP and inflation. Unemployment growth has negative long-run relationship with GDP and positive long-run relationship with inflation. Also, government consumption $\mathrm{t}$-stat. is significant in inflation equation but not significant in real GDP equation. 
Table: 1.3 Short-run causality

\begin{tabular}{|c|c|c|c|c|c|}
\hline 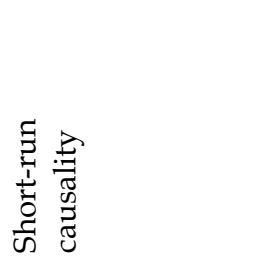 & ๑四 & م & 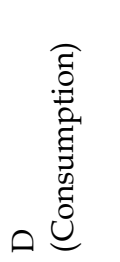 & ๑ & 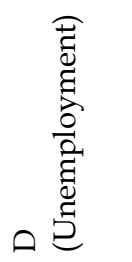 \\
\hline CointEq1 & $\begin{array}{c}-0.105 \\
{[-2.246]} \\
\end{array}$ & $\begin{array}{l}-15.946 \\
{[-1.574]}\end{array}$ & $\begin{array}{c}0.134 \\
{[0.565]}\end{array}$ & $\begin{array}{l}-0.106 \\
{[0.480]}\end{array}$ & $\begin{array}{c}0.135 \\
{[0.951]}\end{array}$ \\
\hline CointEq2 & $\begin{array}{c}0.002 \\
{[0.873]}\end{array}$ & $\begin{array}{c}-0.331 \\
{[-0.663]}\end{array}$ & $\begin{array}{c}0.006 \\
{[0.486]}\end{array}$ & $\begin{array}{c}-0.009 \\
{[-0.797]}\end{array}$ & $\begin{array}{c}-0.038 \\
{[-5.212]}\end{array}$ \\
\hline $\begin{array}{l}\text { D(RGDP } \\
(-1))\end{array}$ & $\begin{array}{c}0.161 \\
{[0.754]}\end{array}$ & $\begin{array}{l}-67.031 \\
{[-1.451]}\end{array}$ & $\begin{array}{c}0.619 \\
{[0.572]}\end{array}$ & $\begin{array}{c}1.139 \\
{[1.127]}\end{array}$ & $\begin{array}{c}0.421 \\
{[0.649]}\end{array}$ \\
\hline $\begin{array}{l}\mathrm{D} \text { (Inflation } \\
(-1))\end{array}$ & $\begin{array}{c}-0.001 \\
{[-0.772]}\end{array}$ & $\begin{array}{c}0.129 \\
{[0.363]}\end{array}$ & $\begin{array}{c}-0.001 \\
{[-0.141]}\end{array}$ & $\begin{array}{c}-0.002 \\
{[-0.213]}\end{array}$ & $\begin{array}{c}0.025 \\
{[5.079]}\end{array}$ \\
\hline $\begin{array}{l}\mathrm{D}(\text { Consumption } \\
(-1))\end{array}$ & $\begin{array}{c}0.044 \\
{[0.774]}\end{array}$ & $\begin{array}{l}24.696 \\
{[2.019]}\end{array}$ & $\begin{array}{c}0.165 \\
{[0.577]}\end{array}$ & $\begin{array}{c}0.161 \\
{[0.603]}\end{array}$ & $\begin{array}{c}-0.581 \\
{[-3.382]}\end{array}$ \\
\hline $\begin{array}{l}\text { D(Corruption } \\
(-1))\end{array}$ & $\begin{array}{c}0.054 \\
{[1.099]}\end{array}$ & $\begin{array}{c}-3.160 \\
{[-0.297]}\end{array}$ & $\begin{array}{c}-0.441 \\
{[-1.777]}\end{array}$ & $\begin{array}{c}-0.070 \\
{[-0.302]}\end{array}$ & $\begin{array}{c}0.088 \\
{[0.592]}\end{array}$ \\
\hline $\begin{array}{l}\text { D(Unemployment } \\
(-1))\end{array}$ & $\begin{array}{c}-0.045 \\
{[-0.892]}\end{array}$ & $\begin{array}{c}-0.145 \\
{[-0.013]}\end{array}$ & $\begin{array}{c}0.359 \\
{[1.417]}\end{array}$ & $\begin{array}{c}0.100 \\
{[0.423]}\end{array}$ & $\begin{array}{c}-0.319 \\
{[-2.102]}\end{array}$ \\
\hline
\end{tabular}

Source: Computed by the researcher using E-view 7.0

Table 1.3 shows that the t-statistics value of government consumption and corruption are not statistically significant in real GDP and inflation equation while, unemployment grow this not statistically significant in the real GDP equation but significant in the inflation equation. These indicate that there is no short-run relationship between government consumption, corruption and unemployment on economic growth. Unemployment has short-run relationship with inflation.

\section{Conclusion and policy recommendation}

Corruption is a significant social and ethical problem that has an important impact on all societies. It is a phenomenon that exists in many countries and constitutes a problem for the economy. Economists and various researchers in recent years have shown a major interest in studying the phenomenon of corruption and its influences on the economic growth and development. Therefore, this study employs causality technique to investigate corruption 
and economic growth in Nigeria from 1980 to 2013.The empirical findings indicate that unit root test shows that the series are integrated at first difference. Since the series are integrated in the same order, co integration test was carried out which shows that a long-run co-integrating relationship exists between the variables. Hence, Error correction test was performed on variables that have long-run co integration relationship. Furthermore, the time-series analysis result shows that corruption and unemployment growth has positive long-run relationship with GDP. Also, the empirics reveal that government consumption, corruption and unemployment growth have no short-run relationship with real GDP. Therefore, the result in the analysis shows that corruption has a strong influence on the output of Nigeria. From the results obtained therein are used to draw a number of policy recommendation and conclusions.

The quality of political structure is an important determinant of the economic behavior of the people in a country and will also explain the economic performance of the country. Corruption is one of the main reasons for institutional failure that characterizes developing countries and leads to destabilizing their long-term economic growth. Therefore, there is a need to formulate and implement policy that will reduce the negative effects of corruption to the nearest minimum. Some such appropriate policy response to corruption should also focus on the punishment of perpetrators and pursue preventive policies i.e. reducing opportunities and incentives to engage in corrupt practices. First, the quality of governance in Nigeria is low. As a result priority should be given to policy that will reform the regulatory quality, rule of law, government effectiveness and other pertinent governance characteristics. There is a need to entrench good governance in every sphere of government activities which is a sine-qua-non for poverty reduction in Nigerian society. It is not enough for political office holders and other government functionaries to preach that the government has zero tolerance for corruption. They should visibly exhibit accountability, transparency, fiscal responsibility and respect for the rule of law while carrying out their official responsibilities. It is important to note that instituting good governance entails replacing the existing weak institutions in the country with strong ones. Secondly, rule of law need to be 
guaranteed in order to protect human rights. Also, there is a need to ensure governmental predictability. Court rulings have to be protected from political interference and judicial independence has to be assured. Successful policy reform in these will help reduce the incidence of corruption as well. A functioning and professional legal system and access to justice are also necessary, in strengthening the rule of law. Also, anticorruption policy should focus on detection and implementation of appropriate sanctions. Third, there is the need to strengthen institutions such as the civil service, EFCC, ICPC, CCB and other institution that can champion the course of anticorruption, which in turn will create interlocking systems of oversight and self-regulation. These institutions have to be free of corruption themselves and should be active in the fight against corruption. For instance, there is a need for equitable reward for workers, where hard work should be adequately compensated and recognized in all facets of our national life. Institutions which are primarily saddled with responsibility of curbing corruption like: ICPC and EFCC should be adequately staffed, funded and devoid of political interference. Lastly, the fight against corruption should include moral education, as values and norms of a society play an important role in the shaping of individuals. And the re-orientation of the people in the society can best be made possible with the help of media, and the people themselves.

In conclusion, based on the findings of this study, it is therefore recommended that the new government in power should know that "business can never be as usual" but rather "business and usual". Therefore, policy holders and other officials should engage in measures that will curb corruption, these measures include: Increasing efforts aimed at providing adequate information about the long-run negative impacts of corruption, more severe measures against corruption should be adopted ensuring that public funds are not embezzled. Such measures could include: examination of records and independent auditing. Conclusively, Government should improve her political determination to fight corruption to a standstill in the economy. Existing exertions by government are producing good outcomes, but there is still a need to expand on these measures due to the complex nature of Nigeria. 
Ibrahim W et al Corruption and Economic Growth in Nigeria (1980-2013)

\section{References}

Ackerman \& R. Susan (1999). Corruption and Government: Causes, Consequences, and Reform. Cambridge: Cambridge University Press, UK.

Abayelu, A. E (2007). Effects of Corruption and Economic Reforms on Economic Growth and Development: Lessons from Nigeria. Being a paper prepared and submitted For African Economic Conference.

Ahmed, Z. \& S.M Dhifallah (2013). Corruption, governance and economic growth in developing countries: Analysis by panel data. International journal of management and business studies. 3(2):1-6.

Ajie, H.A \& O.E Wokekoro (2012).The impact of corruption of sustainable Economic growth and development in Nigeria. International journal of Economics development research and investment. 3(1):1-19.

Akindele, S. T (1995). Corruption: An Analytical Focus on the Problems of its Conceptualization. Ife Psychologia. 3(1):32-56.

Akinpelu, Y.A \& T.O Ogunseye et al. (2013).The socio-economic determinants of corruption in Nigeria. European journal of humanities and social sciences. 19(1):1-17.

Akkihal, R.S. H \& R. Adkins (1997).The Economics of Corruption in Developing Countries. Coastal Business Journal 1:1-10.

Amadi, S. (2004).Privatizing without Reforming: the Case of Nigeria. Report of Civil Society policy dialogue on the National economic empowerment and development strategy (NEEDS). A Publication of the Human Rights Law Services (HURILAWS) and Centre for Public Policy \& Research (CPPR).

Barro, Robert J.(1991). Economic growth in across section of countries. Quarterly Journal of Economics. 106(2):407-443.

Dike, V. E (2003). Managing the challenges of corruption in Nigeria, Center for Social Justice and Human Development (CSJHD), 
Sacramento,

California.http://www.jsdafrica.com/Jsda/Summer1999/

Egunjobi, T.A(2013).An econometric analysis of the impact of corruption on economic growth in Nigeria. Journal of business management and Economics. 4(3):1-12.

Epele, A. (2006). Corruption and the Nigerian Society: Causes, Effects and the Futility of Solutions. The Politics Magazine. University of Benin, Benin City.

Gbenga, L. (2007). Corruption and development in Africa: challenge for political and economic change. Humanity and social sciences journal. 2(1):1-7.

Getz, Kathleen A., Volkema,\& J. Roger (2001).Culture, Perceived Corruption, and Economics: A Model of Predictors and Outcomes. Business and Society. 40(1):7-30.

Gire, J. T (1999): A Psychological Analysis of Corruption in Nigeria. Journal of Sustainable Development. Retrieved 20th April 2014.http:/ / www.jsdafrica.com/Jsda/Summer1999/

Hadi, H. (1999). The Detrimental Effects of Corruption in Developing Countries. Journal of Social Science. Retrieved November, 2014. http://www.andover.edu/ aep/ papers/ 410/hhusain99.pdf.

Husted, Bryan W. (1999). Wealth, Culture, and Corruption. Journal of International Business Studies. 30(2):339-360.

Imohe, E. E (2005).Nigeria's Progress in Curbing Economic Corruption. A Paper Presented at a Forum organized by the Society of Government Economists. Washington, DC 27th September, 2005.

Keeper (2010). Systemic Corruption in Nigeria: A Threat to Sustainable Development. Proceedings of the 1st International Technology, Education and Environment Conference. African Society for Scientific Research (ASSR), Co-Published By: Human Resource Management Academic Research Society. www.hrmars.com/admin/pics/224.pd 
Ibrahim W et al Corruption and Economic Growth in Nigeria (1980-2013)

Krueger, A. O. (1974). The political economy of the rent seeking society. American Economic Review. 64(3): 291-303.

Kwabena, G.B (2001). Corruption, economic growth and income inequality in Africa. Eco.Gov.3:1-27.

Lambsdorff, J.G. (1999). Corruption in empirical research: A Review. Transparency International Working Paper, Berlin.

Lawal, G. (2007). Corruption and Development in Africa: Challenges for Political and Economic Change. Humanity $\mathcal{E}$ Social Sciences Journal. 2(1):01-07.

Leff, N.H. (1964). Economic development through Bureaucratic Corruption. The American Behavioral Scientist 8(2):8-14.

Lipset, S. M. and Lenz, G. S.(2000): Corruption, Culture, and Markets, in Culture Matters,

Lawrence E. Harrison, and Samuel P. Huntington, eds., (New York: Basic Books, (2000)p.112.

Maduagwe, M. O. (1996). Nigeria in Search of Political Culture: The political class, corruption and democratization inNigeria. Alex Gboyegaed 13:18-19.

Mauro, P. (1995). Corruption and Growth. Quarterly Journal of Economics. 110(3):681-712.

Mustapha, S.A \& I.A Ismaila et al. (2011).A parameter debate of corruption and Economic growth insub-Saharan Africa countries. Developing country studies. 3(11):1-13.

Nwabuzor, A. (2005). Corruption and Development: New Initiatives in Economic Openness and strengthened Rule of Law. Publication of Springer. 59(1):121-138.

Nwankwo, O. (2014). Impact of corruption on economic growth in Nigeria. Mediterranean journal of social sciences. 5(6):1-6.

Ogunmuyiwa, M.S (2012).An econometrics analysis of the impact of corruption on FDI in Nigeria. Journal of African macroeconomic review. 2(1):1-13. 
Ojukwu, C.C \& J.O Shopeju (2010). Elite corruption and the culture of primitive accumulation in $21^{\text {st }}$ century Nigeria. International journal of peace and development studies. 1(2):1-10.

Omotola, J. S. (2008).Combating Poverty for Sustainable Human Development in Nigeria: The Continuing Struggle. Journal of Poverty. 12(4):496-517.

Rotimi, E.M \& B. Obasaju et al. (2013).Analysis of corruption and Economic growth in Nigeria. Afro Asian journal of social sciences. 4(4):1-19.

ShleIfer, A. \& W. Robert (1993). Corruption. Quarterly Journal of Economics. 108(3):599-617.

Taylor, T. (2010). Corruption and Liberation: The Experience of Nigeria. Decaritas Journal of Management and Social Sciences. 2(3):1-9.

Tokunbo, M. A. (1992). The challenges of public service.Quarterly journal of Administration.2(2):6-17.

Triumph, O.O \& O.A Olushina (2012). Empirical Nexus between corruption and economic growth (GDP): Across country econometric analysis. International journal of scientific and Research publication. 2(8):1-6. 